УДК 616.12-005.4:616.132.2]-089

\title{
No-touch technique of saphenous vein harvesting for coronary artery bypass grafting gives promise patency rate comparable to that of the left internal thoracic artery
}

\author{
Stukov Y. Y., Rudenko S. A., Sokur S. A., Rudenko M. L. \\ National M. M. Amosov Institute of Cardiovascular Surgery National Academy \\ of the Medical Sciences of Ukraine (Kyiv)
}

\begin{abstract}
The paper presents review of the literature in terms of the advantages of no-touch great saphenous vein (GSV) harvesting technique and its impact on long-term GSV patency for coronary artery bypass grafting compared to conventional method of vein harvesting. Presented detailed pathophysiological mechanisms of venous graft failure, using conventional GSV harvesting.

Purpose. Analysis of literature data for the optimal choice of additional vascular shunt used for coronary bypass grafting in multi - vessel coronary artery disease, based on patency rate.

Conclusion. No-touch technique of GSV harvesting provides better structural, functional, and mechanical protection of the vein wall. Perfecting the technique of this harvesting method and long-term follow up in patients with no-touch GSV grafts may reveal a graft patency comparable to that of LITA.

Key words: coronary artery bypass grafting, no-touch technique of great saphenous vein harvesting, conventional technique of saphenous vein harvesting, multi-vessel coronary disease, surgical revascularization, atherosclerosis, ischemic heart disease.
\end{abstract}

Worldwide, left internal thoracic artery (LITA) is accepted as the 'gold standard' for surgical revascularization and its usage has been steadily increasing. Despite the widespread use of the internal thoracic artery (ITA) and other arterial conduits, the great saphenous vein (GSV) continues to be the most commonly used conduit for coronary artery bypass grafting (CABG) in multi-vessel coronary disease.

The use of the great saphenous vein (GSV) as a conduit for coronary artery bypass grafting (CABG) was first described by Favaloro [1] almost 50 years ago, and this vein remains the most widely used graft despite a patency rate of about $50 \%$ at 10 years compared with more than $90 \%$ for the internal thoracic artery [2, 3, 37]. The outcome of coronary artery bypass grafting with the saphenous vein graft is unsatisfactory because vein grafts are prone to occlusive disease. With vein graft disease and graft closure, symptoms return. This provides occurrence of symptoms, insufficient left ventricular performance, increased need for reoperation, and decreased quality of life and life expectancy rate. More surprisingly, up to $15 \%$ of vein grafts are early occluded, just in the 1 st month and another $15-30 \%$ of them are occluded in the first postCABG year [4, 32]. Vein graft failure is the result of three main causes depending on the time after surgery: acute thrombosis, intimal hyperplasia, and atherosclerosis [5, 27]. The reason for such early occlusion can be explained by surgical technique of vein harvesting. The pedicle of tissue surrounding the SV is composed of fat, elastic tissue, nerves, and vasa vasorum, a network of nourishing microvessels supplying nutrients and oxygen to the blood vessel wall. Vasa vasorum is more pronounced in muscular veins than in arteries and extends deep into the tunica media. With conventional (C) technique of GSV harvesting the surrounding tissue, including parts of the adventitia, is stripped off and the vasa vasorum is damaged. There is experimental evidence that interruption of blood flow through the vasa vasorum in arteries by a close-fitting external cuff results in transmural ischemia that leads to neointimal hyperplasia and the eventual appearance of atherosclerotic lesions [6]. Inasmuch as the requirement for a functional vasa vasorum in veins is greater than in arteries, where oxygen/nutrients are obtained by diffusion from luminal blood, damage to this microvessel network is likely to have consequences that are more serious. Removal and disconnection of the vasa vasorum during conventional SV graft harvesting may therefore be expected to initiate similar events and could contribute to graft failure [7]. During the 1st postoperative month, acute thrombosis is the main cause of graft failure [5, 17]. From 1 to 12 months after surgery (the subacute period), intimal hyperplasia is responsible for graft failure $[5,17$, 30]. Atheroma development following intimal hyperplasia is responsible for graft failure after the 1 st postoperative year $[17,33]$. In large veins, such as the GSV, there is an interaction between the vasa vasorum and the mechanical 
properties of the vessel wall. The $\mathrm{C}$ for vein graft harvesting renders the vein graft spastic and therefore it has to be distended. Increased luminal pressure induces a shape change in the vasa vasorum, from their original circular appearance to an elliptical shape, this results in a reduction of blood flow in the media of the vessel causing loss of the wall elasticity $[7,8]$. The vasa vasorum of the $\mathrm{SV}$ is densely innervated mainly by unmyelinated sympathetic nerves and the presence of several layers of surrounding smooth muscle cells implies that the vessels of the vasa vasorum actively regulate their own tone [9]. It is likely that surgical and distention-induced trauma causes constriction of vasa vasorum and consequent reduction in blood supply to the vessel wall [7]. Furthermore, Malone with colleagues demonstrated that the average venous distention pressure observed during preparation of autogenous vein grafts for arterial implantation was 300 to $500 \mathrm{mmHg}$ and often exceeded $500 \mathrm{mmHg}$ [10]. Consequently, high-pressure distention vessel leading to extensive damage to the endothelium of the vein wall $[11,26,28,35]$. Pressures of $50-60 \mathrm{mmHg}$ did not influence the mechanics of the vein graft, whereas pressures of $75-100 \mathrm{mmHg}$ elevated the elastic modulus of the vein at the low-strain region while pressures above $130 \mathrm{mmHg}$ increased the elastic moduli at both low- and high-strain regions [34].

Souza [12] proposed an innovative «no-touch (NT)» technique for the harvesting of GSV in 1996. No touch technique is an atraumatic approach to remove the GSV complete with its cushion of surrounding tissue without touching the vessel at all. This novel method contributes to better preservation of endothelial integrity and luminal nitric oxide synthase (NOS) [4, 13, 14]. Moreover, the surrounding fat tissue of the vein is a source of several vasoactive factors [4, 15]. When the SV is harvested using the «NT» technique, surgical instruments do not touch at all the vessel itself, so no spasm occurs making the distension of the vein graft unnecessary $[4,16]$, thus further minimizing the endothelial damage caused [8, 17]. Furthermore, the perivascular tissue may act as a natural external stent, reducing the neointimal and medial thickening of the vein graft [36] and preventing it from kinking, which is especially important when using sequential grafts. In conventional preparations the total vasa vasorum area was $37 \%$ lower than that in NT preparations, reflecting a shape change and diminished area of the vasa vasorum in conventional vein grafts [7].

According to Souza et al. [18] the harvesting technique of the GSV for CABG, which is directly related to the preoperative quality of the vein $[18,19]$ constitutes the most significant factor for graft patency [18]. According to this study by Souza et al., the NT technique not only provides a significantly better GSV patency rate in comparison with the conventional technique $(\mathrm{P}=0.007)$ but also $\mathrm{SV}$ patency is similar to that of the LITA [18]. According to an angiography assessment by Souza et al. [20] comparing 52 patients whose veins were harvested by the NT technique with 52 patients submitted to the conventional technique, graft patency of veins harvested with the conventional technique was $89 \%$ versus $95 \%$ for the NT technique at 18 months postoperatively [4]. Same results were reported by Rueda et al. [21], who compared NT technique with the conventional one and with an intermediate harvesting technique. The angiography assessment at a mean of 18 months showed that 118 out of the 124 veins were patent in the NT Group (95.4\%) which was significantly higher than the $88.9 \%(113 / 127)$ patency rate of the conventional group and the $86.2 \%(100 / 116)$ patency rate of the intermediate group $(\mathrm{P}=0.025)$. Even ITA patency rate (91.5\%) was lower than the NT SV patency rate in both studies [4, 20,21]. At 8.5 years postoperatively, there was a clear difference between the two groups. NT Group presented a $90 \% \mathrm{SV}$ graft patency whereas the patency rate of the veins prepared with the conventional technique was only $76 \%(\mathrm{P}=0.01)$ [18]. Furthermore, the NT technique was associated with an impressively higher SV graft patency rate than the conventional technique in veins of poor quality having either varicose or fibrotic changes during surgery. The patency rate of veins harvesting at 8.5 years was $88.9 \%$ versus $36.4 \%$, respectively $(\mathrm{P}=0.002)$ [4, 18]. It is important to mention that the overall long-term LITA patency was $90 \%$ at 8.5 years [18]. In a subsequent study, the same group compared long-term graft patency rates of an SV harvested by the NT technique with a radial artery graft [22]. If harvested by the conventional technique, an $\mathrm{SV}$ graft has a lower long-term patency rate compared to a radial artery [23]. However, the patency rate of the NT SV graft at 3 years was $94 \%$ which was significantly higher than the $82 \%$ patency rate of the radial artery graft $(\mathrm{P}=0.01)[4,22,29]$.

Similarly, Johansson et al. [4,24] compared graft patency rates with a focus on early atherosclerotic changes between veins harvested by the NT technique and by the conventional technique in a short term at 18 months and in a long term at 8.5 years study. In the short-term study, graft patency was $89 \%$ for the NT Group, whereas it was $75 \%$ for the conventional group ( $\mathrm{P}=0.006)$. A bolus of 12,500 IU of heparin intravenous and $0.2 \mathrm{mg}$ nitroglycerin was administered and then intravascular ultrasonography was performed. If the diameter of the target coronary artery was over $2 \mathrm{~mm}$ forming a favorable angle with the SV graft, the ultrasound catheter was advanced into the coronary artery, or else it was advanced close to the junction of the graft with the coronary vessel. [4, 24] Intravascular ultrasonography showed less intimal thickness $(\mathrm{P}=0.03)$, less grafts with considerable intimal hyperplasia $(\mathrm{P}=0.011)$, and larger graft lumen volumes $(\mathrm{P}=0.07)$ in the NT Group. In the long-term study ( 8.5 years), the NT technique was associated with a $92.3 \%$ patency rate which was superior to the $84.4 \%$ patency rate of the conventional technique $(\mathrm{P}=0.14) \quad[4,24]$. Intravascular ultrasonography also 
revealed much more intense atherosclerotic changes in the conventional group at 8.5 years. In overall, fewer patients in the NT Group had grafts containing plaque compared to the conventional group $(50 \%$ vs. $80 \%, \mathrm{P}=0.13)$. In detail, comparing the NT group to the conventional one, there were significantly fewer grafts containing multiple plaques in the former $(14.8 \%$ vs. $50 \%, \mathrm{P}=0.008)$, significantly less advanced plaque with lipid (11.8\% vs. $63.9 \%, \mathrm{P}=0.0004)$ and significantly less maximal plaque thickness ( $1.04 \mathrm{~mm}$ vs. $1.32 \mathrm{~mm}, \mathrm{P}=0.02)$. Finally, lumen volumes continued to be significantly larger in the NT Group $(\mathrm{P}=0.03)[4,24]$.

According to different studies, no-touch vein graft, at a mean time of 16 years [25, 31], maintains a significantly higher patency rate than conventional harvesting of GSV grafts and still has patency comparable to that of the left internal thoracic artery (LITA) [38].

Conclusions. NT technique of GSV harvesting provides better structural, functional, and mechanical protection of the vein wall. Perfecting the technique of this harvesting method and long-term follow up in patients with NT GSV grafts may reveal a graft patency comparable to that of LITA.

\section{Literature}

1. Favaloro R. G. Saphenous vein graft in the surgical treatment of coronary artery disease: operative technique $\mid / /$ J Thorac Cardiovasc Surg. - 1969. - Vol. 58. - P. 178-185.

2. Nwasokwa O. N. Coronary artery bypass graft disease // Ann Intern Med. - 1995. - Vol. 123. - P. 528-45. [PubMed]

3. Coronary bypass graft fate and patient outcome: angiographic follow-up of 5,065 grafts related to survival and reoperation in 1,388 patients during 25 years / Fitzgibbon G. M., Kafka H. P., Leach A. J. et al. // J Am Coll Cardiol. - 1996.- Vol. 28. - P. 616-26. [PubMed]

4. Novel no touch technique of saphenous vein harvesting: Is great graft patency rate provided? / Papakonstantinou NA, Baikoussis NG, Goudevenos J et al. // Ann Card Anaesth. - 2016. - Vol. 19. - P. 481-8.

5. Parang P., Arora R. Coronary vein graft disease: Pathogenesis and prevention // Can J Cardiol. - 2009. Vol. 25. - e57-62.

6. Arterial intimal hyperplasia after occlusion of the adventitial vasa vasorum in the pig / S. G. Barker, A. Talbert, S. Cottam et al. // Arterioscler Thromb. - 1993. - Vol. 13. - P. 70-77.

7. The "no-touch" harvesting technique for vein grafts in coronary artery bypass surgery preserves an intact vasa vasorum / Mats Dreifaldt, Domingos S. R. Souza, Andrzej Loesch et al. // The Journal of Thoracic and Cardiovascular Surgery. - Jan 2011. - Vol. 141, Issue 1. P. 145-150.

8. Modeling of elastic deformation and vascular resistance of arterial and venous vasa vasorum / G. Maurice, X. Wang, B. Lehalle, J. F. Stoltz // J Mal Vasc. - 1998. - Vol. 23. P. 282-288.

9. Scotland R. S., Vallance P. J., Ahluwalia A. Endogenous factors involved in regulation of tone of arterial vasa vasorum: implications for conduit vessel physiology// Cardiovasc Res. - 2000. - Vol. 46. - P. 403-411.

10. Malone J. M., Kischer C. W., Moore W. S. Changes in venous endothelial fibrinolytic activity and histology with in vitro venous distention and arterial implantation // Am J Surg. - 1981. - Vol. 142. - P. 178-82.

11. Nature and pressure dependence of damage induced by distension of human saphenous vein coronary artery bypass grafts / Angelini G. D., Passani S. L., Breckenridge I. M. et al. // Cardiovasc Res. - 1987. - Vol. 21. - P. 902-7.

12. Souza D. A new no-touch preparation technique. Technical notes // Scand J Thorac Cardiovasc Surg. - 1996. Vol. 30. - P. 41-4.

13. «No-touch» technique using saphenous vein harvested with its surrounding tissue for coronary artery bypass grafting maintains an intact endothelium / Souza D. S., Christofferson R. H., Bomfim V. et al. // Scand Cardiovasc J. - 1999. - Vol. 33. - P. 323-9.

14. Preserved endothelial integrity and nitric oxide synthase in human saphenous vein harvested by a novel 'no-touch' technique / Tsui J., Souza D. S., Filbey D. et al. // Br J Surg. - 2001. - Vol. 88. - P. 1209-15.

15. Gollasch M., Dubrovska G. Paracrine role for periadventitial adipose tissue in the regulation of arterial tone // Trends Pharmacol Sci. - 2004. - Vol. 25. - P. 647-53.

16. High early patency of saphenous vein graft for coronary artery bypass harvested with surrounding tissue / Souza D. S, Bomfim V., Skoglund H. et al. // Ann Thorac Surg. - 2001. - Vol. 71. - P. 797-800.

17. Localization of nitric oxide synthase in saphenous vein grafts harvested with a novel «no-touch» technique: Potential role of nitric oxide contribution to improved early graft patency rates / Tsui J. C., Souza D. S., Filbey D. et al. // J Vasc Surg. - 2002. - Vol. 35. - P. 356-62.

18. Harvesting the saphenous vein with surrounding tissue for CABG provides long-term graft patency comparable to the left internal thoracic artery: Results of a randomized longitudinal trial / Souza D. S., Johansson B., Војц L. et al. // J Thorac Cardiovasc Surg. - 2006.- Vol. 132. P. 373-8.

19. Intimal hyperplasia and expression of transforming growth factor-beta1 in saphenous veins and internal mammary arteries before coronary artery surgery / Friedl R., Li J., Schumacher B. et al. // Ann Thorac Surg. - 2004. Vol. 78. - P. 1312-8.

20. Improved patency in vein grafts harvested with surrounding tissue: Results of a randomized study using three harvesting techniques / Souza D. S., Dashwood M. R., Tsui J. C. et al. // Ann Thorac Surg. - 2002. - Vol. 73. - P. 1189-95.

21. Novel no-touch technique of harvesting the saphenous vein for coronary artery bypass grafting / Rueda F. D., Souza D., Lima Rde C et al. // Arq Bras Cardiol. - 2008. - Vol. 90. P. 356-62.

22. The no-touch saphenous vein as the preferred second conduit for coronary artery bypass grafting / Dreifaldt M., Mannion J. D., Bodin L. et al. // Ann Thorac Surg. 2013. - Vol. 96. - P. 105-11.

23. RAPS Investigators. Radial artery and saphenous vein patency more than 5 years after coronary artery bypass 
surgery: Results from RAPS (Radial Artery Patency Study) / Deb S., Cohen E. A., Singh S. K. et al. // J Am Coll Cardiol. - 2012. - Vol. 60. - P. 28-35.

24. Slower progression of atherosclerosis in vein grafts harvested with 'no touch' technique compared with conventional harvesting technique in coronary artery bypass grafting: An angiographic and intravascular ultrasound study / Johansson B. L., Souza D. S., Bodin L. et al. // Eur J Cardiothorac Surg. - 2010. - Vol. 38. - P. 414-9.

25 . The no-touch saphenous vein for coronary artery bypass grafting maintains a patency, after 16 years, comparable to the left internal thoracic artery: A randomized trial / Ninos Samano, Hakan Geijer, Mats Liden et al. // The Journal of Thoracic and Cardiovascular Surgery. - Oct 2015. Vol. 150, Issue 4. - P. 880-888.

26. Saphenous vein graft harvesting and patency: no-touch harvesting is the answer / Domingos Ramos De Souza, MD, PhD, Michael R. Dashwood, PhD, Ninos Samano, MD, PhD // J Thorac Cardiovasc Surg. - Oct 2017. Vol. 154, Issue 4. - P. 1300-1301.

27. Benedetto, U. and Angelini, G. D. Saphenous Vein Graft Harvesting and patency: still an unanswered question // J Thorac Cardiovasc Surg. - Nov 2016. - Vol. 152, Issue 5. P. $1462-1463$.

28. Eric S. Wise and Colleen M. Brophy The Case for Endothelial Preservation via Pressure-Regulated Distension in the Preparation of Autologous Saphenous Vein Conduits in Cardiac and Peripheral Bypass Operations // Front Surg. - 2016. - Vol. 3: - P. 54. PMC5031700.

29. The No-Touch Saphenous Vein as the Preferred Second Conduit for Coronary Artery Bypass Grafting / Mats Dreifaldt, MD, John D. Mannion, MD, PhD, Lennart Bodin, PhD, et al. // J Thorac Cardiovasc Surg. - July 2013. - Vol. 96, Issue 1. - P. 105-111.

30. Pedicled no-touch saphenous vein graft harvest limits vascular smooth muscle cell activation: the PATENT saphenous vein graft study / Verma S., Lovren F., Pan Y. et al. // Eur J Cardiothorac Surg. - 2014 Apr. - Vol. 45 (4). - P. 717-25.

31. The no-touch vein graft for coronary artery bypass surgery preserves the left ventricular ejection fraction at 16 years postoperatively: long-term data from a longitudinal randomised trial / Johansson B., Samano N., Souza D. et al. // Open Heart. - 2015. - Vol. 2:e000204. doi: 10.1136/ openhrt-2014-000204

32. Pressure Control During Preparation of Saphenous Veins / Li F. D., Eagle S., Brophy C. et al. // JAMA Surg. - 2014. - Vol. 149 (7). - P. 655-662. doi: 10.1001/ jamasurg.2013.5067

33. Correlates of Saphenous Vein Graft Hyperplasia and Occlusion 1 Year After Coronary Artery Bypass Grafting Analysis From the CASCADE Randomized Trial / Dai Une, MD; Alexander Kulik, MD; Pierre Voisine, MD; et al. // Circulation. - 2013. - Vol. 128. -S213-S218.

34. Necla Ozturk, Nehir Sucu, Ulku Comelekoglu et al. // Pressure applied during surgery alters the biomechanical properties of human saphenous vein graft / Heart and Vessels. - 2013. - Vol. 28, N 2. - P. 237.

35. Surgical vein graft preparation promotes cellular dysfunction, oxidative stress, and intimal hyperplasia in human saphenous vein / Michael J. Osgood et al. // Journal of vascular surgery. - July 2014. - Vol. 60, Issue 1. P. 202-211.

36. Taggart, D., Nir, R. R., and Bolotin, G. New technologies in coronary artery surgery // Rambam Maimonides Med J. - 2013. - Vol. 4. - e0018.

37. Low nanomolar thapsigargin inhibits the replication of vascular smooth muscle cells through reversible endoplasmic reticular stress / Shukla N., Wan S., Angelini G. D. et al. // Eur J Pharmacol. - 2013. - Vol. 714.- P. 210-217.

38. Max Baghai, Lindsay C. H. John, MD. Look but don't touch! An alternative to the gold standard? // The Journal of Thoracic and Cardiovascular Surgery August 2017. Vol. 154, Issue 2. - P. 467-468.

\title{
Порівняння функціональної надійності венозного шунта, виділеного за методикою no-touch при операції аортокоронарного шунтування, та внутрішньої грудної артерії
}

\author{
Стуков Ю. Ю., Руденко С. А., Сокур С. А., Руденко М. Л. \\ ДУ «Національний інститут серцево-судинної хірургії імені М. М. Амосова НАМН» (Київ)
}

У статті представлено огляд літератури, що доводить перевагу методики no-touch виділення великої підшкірної вени ноги при операції аортокоронарного шунтування порівняно зі стандартною методикою у зниженні частоти порушення функції венозних шунтів в ранньому, середньому і віддаленому післяопераційному періоді. Детально описано патофізіологічні механізми тромбозу венозного шунта при використанні стандартної методики виділення великої підшкірної вени ноги.

Мета роботи - аналіз літературних даних для оптимального вибору шунта при мультисудинному ураженні коронарних артерій.

Висновки. No-touch методика виділення великої підшкірної вени ноги забезпечує кращий структурний і механічний захист стінки вени. Використання методики n-touch може виявити функціональну надійність венозного шунта, що можна порівняти з внутрішньою грудною артерією.

Ключові слова: аортокоронарне шунтування, по-тоисһ техніка виділення великої підшкірної вени стегнової кістки, стандартна методика виділення великої підшкірної вени ноги, мультисудинне ураження коронарних артерій, ішемічна хвороба серия, хірургічна реваскуляризація, атеросклероз. 


\title{
Сравнение функциональной надежности венозного шунта, выделенного по методике no-touch при операции аортокоронарного шунтирования, и внутренней грудной артерии
}

\author{
Стуков Ю. Ю., Руденко С. А., Сокур С. А., Руденко М. Л. \\ ГУ «Национальный институт сердечно-сосудистой хирургии имени Н. М. Амосова НАМН» (Киев)
}

В статье представлен обзор литературы, доказывающий преимущество методики no-touch выделения большой подкожной вены ноги при операции аортокоронарного шунтирования по сравнению со стандартной методикой в снижении частоты нарушения функции венозных шунтов в раннем, среднем и отдаленных сроках послеоперационного периода. Детально описаны патофизиологические механизмы тромбоза венозного шунта при использовании стандартной методики выделения большой подкожной вены ноги.

Цель работы - анализ литературных данных для оптимального выбора шунта при мультисосудистом поражении коронарных артерий.

Выводы. No-touch методика выделения большой подкожной вены ноги при операции аортокоронарного шунтирования обеспечивает лучшую структурную и механическую защиту стенки вены. Использование методики no-touch может выявить функциональную надежность венозного шунта, сопоставимого с внутренней грудной артерией.

Ключевые слова: аортокоронарное шунтирование, техника по--оисһ выделения большой подкожной вены ноги, стандартная методикя выделения большой подкожной вены ноги, мультисосудистое поражение коронарных артерий, ишемическая болезнь сердиа, хирургическая реваскуляризация, атеросклероз. 